\title{
Effect of Citric Acid and Lyophilized Autologous Plasma on Healing Following Periodontal Flap Surgery in Monkeys*
}

\author{
Carlos E. Nasjleti, $\uparrow$ Raul G. Caffesse, $\ddagger$ Walter A. Castelli§ \\ Billy A. Smith,‡ Dennis E. Lopatin\| and Charles J. Kowalski\|
}

Accepted for publication 6 April 1987

\begin{abstract}
THE PURPOSE OF THIS HISTOLOGIC, histometric, and autoradiographic study was to examine the effect of citric acid conditioning and lyophilized autologous plasma (LAP) application on healing following periodontal flap surgery. Mucoperiosteal flaps were elevated in six rhesus monkeys using the modified Widman flap procedure. A total of 24 quadrants were treated, each included the first and second premolar and first and second molar teeth. Cementum was removed from the exposed root surfaces, and reference notches were inscribed into the roots at the alveolar bone margin. Two treatment modalities were employed: (1) surgery plus citric acid conditioning, to serve as control and (2) surgery plus citric acid followed by LAP application $(400 \mathrm{mg} / \mathrm{ml}$ saline). Flaps were returned to their preoperative positions and sutured. Animal sacrifices were scheduled to provide observations $3,7,14,21,28$, and 45 days after surgery. Each monkey received an intravenous injection of tritiated thymidine, $1 \mu \mathrm{Ci} / \mathrm{gm}$ of body weight, 1 hour before it was killed. Tissue specimens were processed for evaluation following standard procedures. Histologically, tissue sections were examined for: (1) proliferation and attachment of epithelium, (2) organization and maturation of periodontal fibers, (3) inflammatory cell types, (4) presence or absence of new cementum deposition, and (5) degree of vascularity of the tissues. For histometric evaluation, the radicular notches were used as reference points. The distances examined histometrically were: (1) from the root surface notch to the alveolar bone crest, (2) from the root surface notch to the apical extent of the junctional epithelium, and (3) from the free gingival margin to the apical extent of the junctional epithelium. For autoradiographic evaluation labeled cells were counted in five spatial compartments at $400 \times$ magnification: (1) oral epithelium, (2) crevicular area, (3) supracrestal connective tissue, (4) coronal periodontal membrane, and (5) coronal bone marrow. For each the histometric and autoradiographic evaluation involved a total of 36 tissue sections per quadrant ( 9 sections per tooth). Tooth and quadrant means were obtained for each monkey. The plasma-treated and control quadrants were compared at each time point by the paired $t$ test. $N=2$ monkeys were used for each comparison. Histologic results showed that in teeth that were acid-conditioned after root planing, the epithelium often migrated apically reaching the radicular notch. Those teeth that were conditioned and subsequently treated with LAP demonstrated fiber attachment to the planed root surface and little or no epithelial downgrowth. Histometric results revealed statistically significant differences between LAP-treated and control teeth for at least some of the measurements at every time point except 14 days. Autoradiographic results did not reveal significant differences between LAP-treated and control teeth except in a few instances. Consistently, however, LAP-treated teeth demonstrated more labeled cells than control teeth. After periodontal flap surgery, citric acid conditioning followed by LAP application appears to enhance healing.
\end{abstract}

The quest for a biologic adhesive sealant to accelerate healing following periodontal surgery is not new. Von

* This investigation was supported by the Medical Research Division of the Veterans Administration.

$\dagger$ Dental Research Program, Veterans Administration Medical Center, Ann Arbor, MI 48105.

$\ddagger$ Department of Periodontics, The University of Michigan School of Dentistry, Ann Arbor, MI 48109.
Birger Oestmann, a Swedish dentist, during the 30's appears to have been the first to advocate the use of a commercial kit, tissue adhesive Vivocoll for the pur-

$\S$ Department of Anatomy and Cell Biology, The University of Michigan Medical School.

|| Dental Research Institute, The University of Michigan School of Dentistry.

I Vivocoll, Pearson \& Co, Hamburg, Germany. 
pose of enhancing healing following periodontal flap surgery. ${ }^{.}$The kit consisted of two ampules, one ampule contained cow-blood plasma along with sodium citrate and the other contained calcium chloride, which after mixing produced a sticky gel. Following removal of epithelium and diseased cementum, the gel was applied onto the root surfaces and flap tissues. According to Oestmann, this produced two mesenchymal surfaces which accelerated healing, with fibrin as the binding agent. However, no histologic description was given. Bartolucci and Pini Prato $^{2}$ in 1982 reported preliminary clinical observations on the use of a tissue sealing system Tissucol* in periodontal surgery. This sealing system, which contains human plasma factor XIIIa, fibrinogen, and fibronectin, when mixed with a solution containing thrombin, calcium chloride, and aprotinin, initiates the clotting reaction. The bonding properties of this system were tested on a lateral pedicle flap and on a free gingival graft. $^{2}$ The sealed tissues showed negligible local inflammation following surgery. All biomechanical requirements were met with the flap and the graft remained in the desired position. These authors in 1983 and 1985 reported additional observations on the use of Tissucol in periodontal surgery, ${ }^{3.4}$ and concluded that: (1) Tissucol has hemostatic capabilities when used in periodontal surgical wounds due to the presence of plasma factor XIIIa, (2) it has excellent tissue adhesive properties and is superior to silk suturing, particularly during the first two weeks following surgery, and (3) it causes less wound inflammation than silk sutures during these two weeks of healing.

Ripamonti and Lemmer ${ }^{5}$ in 1984 histologically evaluated the healing of the root-soft tissue interface and the potential for regeneration of the connective tissue attachment in a human after periodontal flap surgery followed by citric acid conditioning of the exposed root and by application of a fibrin adhesive system Tisseel. $\dagger$ Like Tissucol, essential constituents in this system are: human plasma factor XIIIa, fibronectin, fibrinogen, and bovine thrombin. Four months after surgery, newly formed connective tissue fibers were oriented perpendicularly and nearly perpendicularly to the root surface and were inserted into a substantial but discontinuous layer of newly formed cementum. It was postulated that, any or all of the mechanisms related to fibrin, fibronectin, and factor XIIIa may have operated, facilitating the linking of new connective tissue to the root surface collagen exposed by demineralization. ${ }^{5}$ Similarly, Topoll ${ }^{6}$ in 1986 reported the formation of a connective tissue new attachment after citric acid conditioning and application of tissue adhesive Tissucol.

Using the tooth replantation model in monkeys, Caton et al. $^{7}$ in 1986 evaluated periodontal healing following replantation. They evaluated healing after application of Tissucol to denuded and citric acid-

\footnotetext{
* Tissucol, Immuno AG, Industriestrasse 72, Vienna, Austria.
}

$\dagger$ Tisseel, Immuno AG, Industriestrasse 72, Vienna, Austria. treated root surfaces. In teeth replanted after root planing alone and root planing plus tissue adhesive, epithelium migrated apically and was within the periodontal membrane space lining the denuded root at seven days. In contrast, those teeth that were acid-conditioned prior to application of tissue adhesive showed fiber attachment to the planed root surface and little or no epithelial downgrowth. Using the tooth replantation model in monkeys, but without citric acid conditioning, Nasjleti et al. ${ }^{8}$ evaluated the effect of lyophilized autologous plasma (LAP) application on periodontal healing. LAP contains plasma factor XIIIa, fibronectin and fibrinogen. ${ }^{8}$ Teeth that received LAP attained remarkably greater connective tissue reattachment than LAPuntreated teeth.

The purpose of the present study was to assess, histologically, histometrically and autoradiographically, the difference in periodontal healing after flap surgery and citric acid conditioning of root surfaces, with and without LAP application.

\section{MATERIALS AND METHODS}

Six adult male rhesus monkeys (Macaca mulatta), in good systemic health and with an average weight of 5 $\mathrm{kg}$, were used for this study. The selection of the animals was based upon the presence of an intact dentition. Two weeks before the experiment, all teeth were scaled and polished. Sedation was obtained by injecting ketamine hydrochloride intramuscularly $(25 \mathrm{mg} / \mathrm{ml})$. Tooth cleaning was performed every two to three days throughout the experimental period. Each experimental condition was performed in duplicate as follows: monkeys one and two were used to evaluate healing after three and seven days, monkeys three and four for evaluating 14 and 21 days, and monkeys five and six were used to evaluate healing 28 and 45 days following surgery. After the surgical procedures, the animals were maintained on a soft diet supplemented with fresh fruit and water ad libitum.

Citric acid was obtained in anhydrous form. It was mixed to saturation in sterile saline at room temperature and verified to a $\mathrm{pH}$ of 1 with a $\mathrm{pH}$ meter. Fresh solutions of citric acid were prepared prior to each surgery. For the preparation of the lyophilized autologous plasma, samples of 40 to $50 \mathrm{ml}$ of peripheral venous blood was obtained from each monkey and transferred to sterile acid/citrate/dextrose tubes. These tubes then were centrifuged at $130 \mathrm{~g}$ for ten minutes and the supernatant plasma transferred to sterile bottles for lyophilization. The resulting freeze-dried product was stored at $-20^{\circ} \mathrm{C}$ until use. On the day of surgery, bottles were allowed to come to room temperature. Upon reconstitution in normal saline, a viscous sticky solution was obtained.

\section{Surgical Procedures}

A total of 24 quadrants were treated; each included the first and second premolar and first and second 
molar teeth. A split mouth design was used with a contralateral quadrant randomly assigned. General anesthesia was obtained by injecting pentobarbital sodium (Nembutal) intravenously $(30 \mathrm{mg} / \mathrm{ml})$. Prior to surgery, each monkey was locally anesthetized with 1.0 to $1.5 \mathrm{ml}$ of a $2 \%$ xylocaine epinephrine solution, $1: 50,000$. Of the quadrants available in each monkey, two were treated surgically by the modified Widman flap procedure ${ }^{9}$ and citric acid demineralization. After surgical exposure, the roots were thoroughly scaled and planed, and then conditioned with the citric acid solution which was applied with cotton pledgets for three minutes. These pledgets were replaced after 90 seconds. The area was then thoroughly rinsed with sterile saline. Reference radicular notches were placed with a $1 / 2$ round bur at the alveolar bone level to be used as landmarks for the histometric evaluation. These furrows were positioned on the buccal aspect of each tooth in the quadrant and extended into the furcation. Repositioning of the flaps at the cementoenamel junctions was performed with interrupted interproximal sutures (atraumatic Ethicon needle and 0000 braided silk). No dressings were placed and the sutures were removed after seven days. The other two quadrants were treated similarly, but after citric acid demineralization and rinsing with sterile saline, LAP was applied. For this, the root surfaces and the inner aspect of the flaps were bathed with $1 \mathrm{ml}$ of the reconstituted LAP-saline solution $(400 \mathrm{mg} / \mathrm{ml})$, using a tuberculine syringe. Excess solution was absorbed with sterile gauze. To enhance flap adaptation and promote the formation of a thin fibrin clot moderate pressure was applied over the flap for three minutes with a saline-moist sterile gauze. Following surgery, the thrice weekly cleaning schedule was maintained with the modification that, in order to minimize mechanical injury to the marginal tissues, a cotton-tip applicator soaked in $2 \%$ chlorhexidine solution was used to clean the teeth. The monkeys, which were killed with an overdose of sodium pentobarbital, were scheduled to provide observations at $3,7,14,21$, 28 , and 45 days after surgery. One hour before each monkey was killed, an intravenous injection of ${ }^{3} \mathrm{H}$ TDR, $1 \mu \mathrm{Ci} / \mathrm{gm}$ of body weight, Specific Activity 6.7 $\mathrm{Ci} / \mathrm{mmol}^{*}$ was administered. Following exsanguination, the heads of the animals were perfused with $10 \%$ neutral buffered formalin and refrigerated for 24 hours.

\section{Laboratory Procedures}

The jaws were dissected free with the adjacent soft tissues and fixed in $10 \%$ neutral buffered formalin. The jaws were trimmed and then sectioned into appropriate segments and demineralized in 10\% EDTA for four to five months. The demineralized tissue blocks were washed under running water for 24 hours, dehydrated in alcohol, infiltrated, and embedded in paraffin and

\footnotetext{
* New England Nuclear, Billerica, MA.
}

serially cut in the buccolingual plane into $6 \mu \mathrm{m}$ sections. Every fifth section was placed on a glass slide and processed for autoradiographic evaluation. ${ }^{10}$ Some tissue sections were stained with Harris's hematoxylin and eosin and others were stained with Masson's or Mallory's connective tissue stain. For both the histologic and the histometric evaluations, 36 tissue sections from each of the surgically treated quadrants were evaluated using a binocular microscope at $100 \times$ magnification. In addition, 36 sections were evaluated at $400 \times$ magnification for the autoradiographic evaluation.

From each experimental and control tooth, nine stepserial sections representing intervals of $0.4 \mathrm{~mm}$ were used. The sections consisted of the midsection, four step-serial sections mesial to the midsection and four step-serial sections distal to the midsection. The midsection was identified as the section which divided the anatomical tooth crown into two halves. This procedure allowed an equal number of sections for evaluating both mesial and distal halves of each tooth. Consequently, 36 buccolingual sections for each treatment modality, per monkey and time point, were examined for each evaluation.

\section{Histologic Evaluation}

For this evaluation, tissue sections were examined for: (1) proliferation and attachment of epithelium, (2) organization and maturation of periodontal fibers, (3) inflammatory cell types, (4) presence or absence of new cementum deposition, and (5) degree of vascularity of the tissues.

\section{Histometric Evaluation}

Histometric measurements were made with a Filar micrometer eyepiece $\dagger$ held parallel to the specimen surface. The apical border of the radicular notch was the primary reference point. The distances examined (Fig. 1) were: (1) from the root surface notch to the alveolar bone crest, (2) from the root surface notch to the apical extent of the junctional epithelium, and (3) from the free gingival margin to the apical extent of the junctional epithelium. The eyepiece was calibrated at $100 \times$ magnification using the grid of a hemocytometer. A total of 864 tissue sections were histometrically evaluated, 432 treated with LAP and 432 without it. The measured distances were subsequently used to obtain the histometric data, which were expressed in $\mathrm{mm}$. For each of the two treatment modalities, tooth means and quadrant means were computed for each monkey and at each time-point.

\section{Autoradiographic Evaluation}

Epithelial, connective tissue and bone marrow labeled cells were counted in the periodontium associated

† Filar Micrometer Eyepiece, Bausch and Lomb Optical Co, Rochester, NY. 


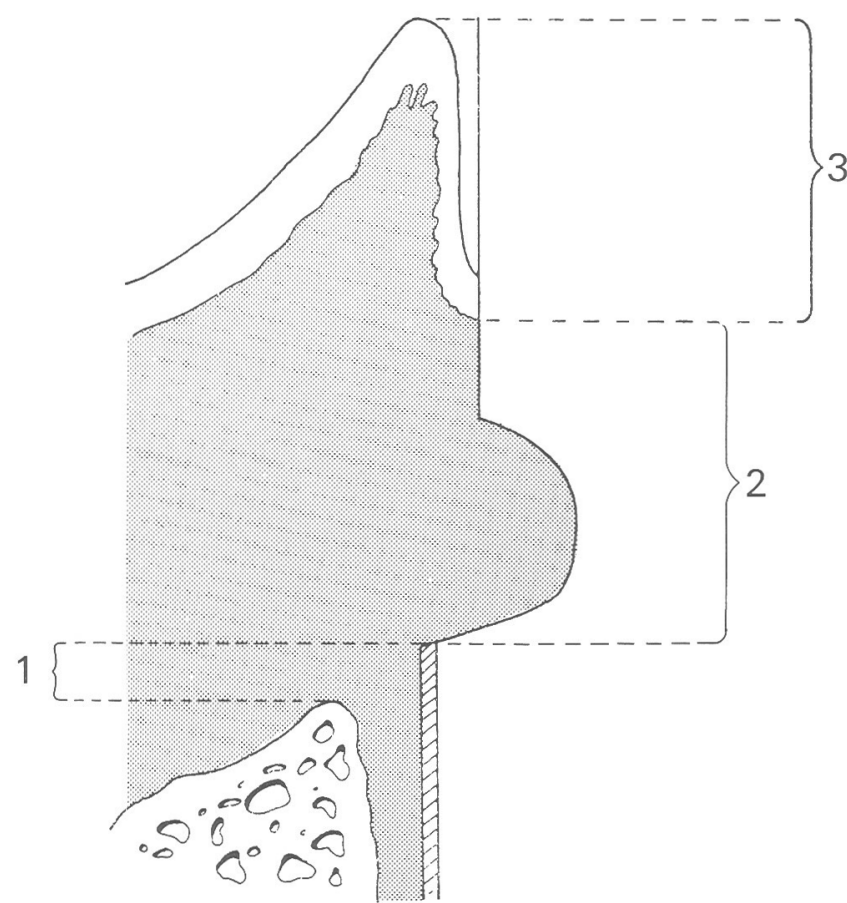

Figure 1. Diagram showing the distances examined histometrically.

with each experimental and control tooth. For this purpose, the periodontium was divided into five different spatial compartments (Fig. 2): (1) oral epithelium, (2) crevicular area, (3) supracrestal connective tissue, (4) coronal periodontal membrane, and (5) coronal bone marrow. For counting labeled cells, a Veeder hand-tally counter* was used. A total of 864 tissue sections were autoradiographically evaluated, 432 treated with LAP and 432 without it. For each of these two groups, tooth means as well as quadrant means were computed for each monkey and for each timepoint.

\section{Statistical Analysis}

The LAP-treated and control quadrants were compared at each time point by the paired $t$ test. $N=2$ monkeys were used for each comparison. ${ }^{11}$

\section{RESULTS}

In all quadrants, regardless of the treatment modality used, clinical healing progressed in a similar and uneventful manner. A histological analysis revealed no abnormal hard or soft tissue reaction following the topical application of citric acid alone or citric acid plus LAP.

\section{Histologic}

There were histologic differences between LAPtreated and control quadrants at 3, 7, 14 and 21 days following surgery. There were distinct differences in

\footnotetext{
* Veeder-Root, Hartford, CT.
}

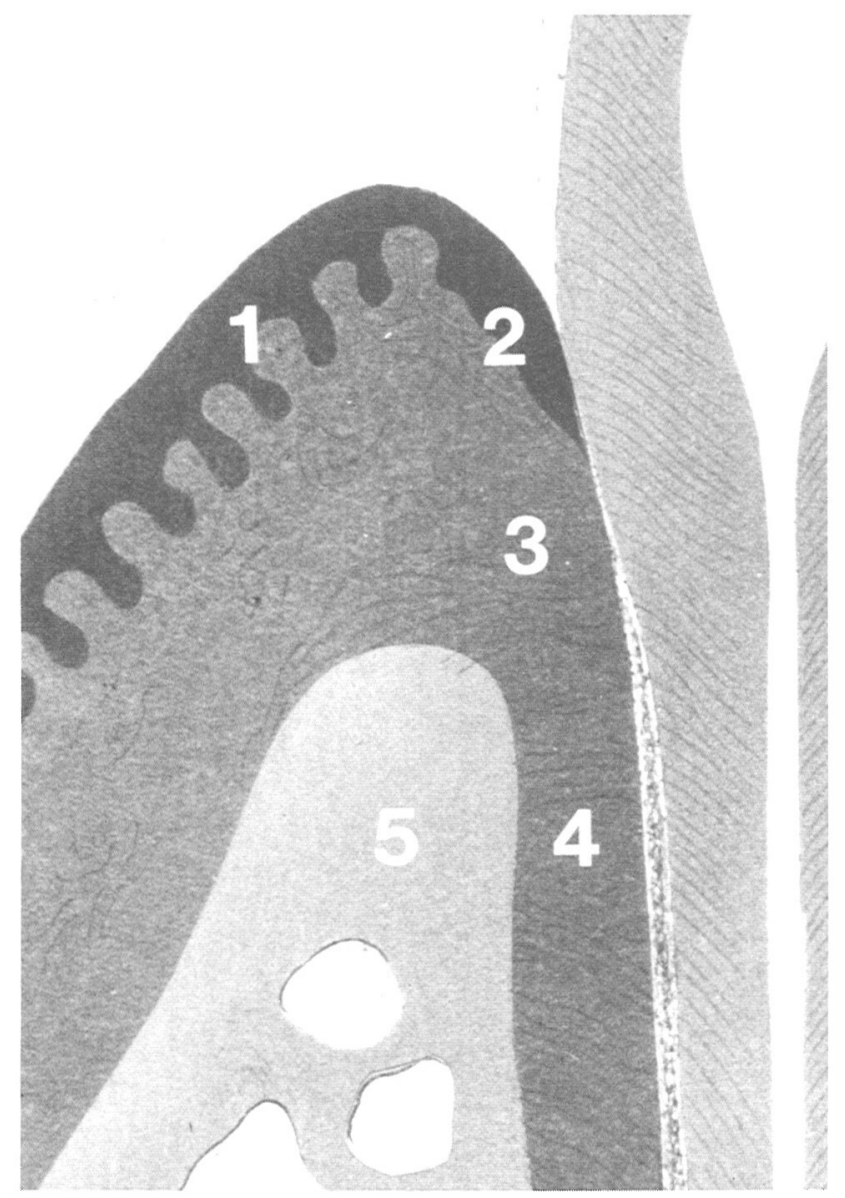

Figure 2. Diagram showing location of the five spatial cell compartments where the autoradiographic evaluations were performed.

terms of degree of surgically induced inflammation, and the rate and quality of healing. After 21 days, the differences that existed were negligible.

Three-Day Specimens. In LAP-treated specimens, a mixed fibrinous hemorrhagic exudate composed of neutrophils, lymphocytes and some mononuclear phagocytes (monocytes or macrophages) filled the surgically created interface and the radicular notch. A typical meshwork was evident close to the alveolar bone (Fig. 3A). Fibroblast engorgement with indication of mitotic activity was found in this cell population in areas of the coronal periodontal membrane and in the connective tissue bounding the interface. Engorged endothelial cells were also evident and limited to places similar to those of fibroblasts. Epithelial proliferation started at the marginal gingiva with long flat cells invading the crevicular surface. In contrast, the control specimens demonstrated the following: (1) a thin fibrinous meshwork filled the entire interface and radicular notch (Fig. 3B), (2) scattered mononuclear cells were only contained in the meshwork, (3) the largest accumulation of leukocytes occurred at the vital margins of the interface, and (4) fibroblastic response was discrete with cell engorgement which was mainly detected at the coronal periodontal membrane. 

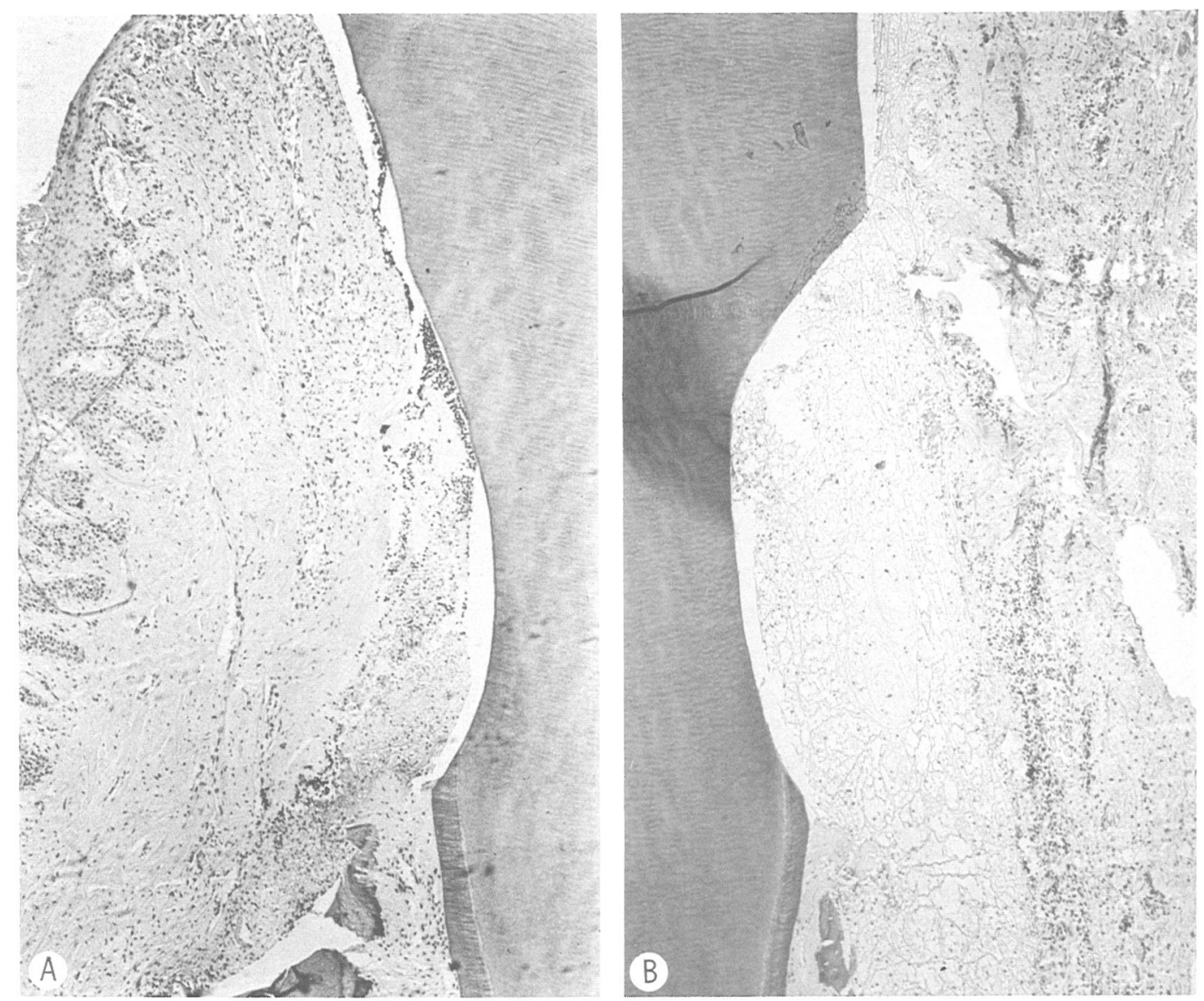

Figure 3. Three-day specimens. Overall view of the fibrin meshwork filling the surgically created interface. A. LAP-treated inflammatory cells are evenly distributed within the meshwork. B. Control. Most inflammatory cells are concentrated at the vital margins of the interface (hematoxylin and eosin, magnification $\times 25$ ).

Seven-Day Specimens. Each of the LAP-treated specimens showed repairing connective tissue that filled the radicular notch and the interface formed by thick collagenous bundles and abundant enlarged fibroblasts (Fig. 4A). There were only scattered blood vessels in the tissue. An inflammatory infiltrate containing lymphocytes, macrophages, and neutrophils was present deep in the crevicular area. There was intense fibroblastic activity with collagen deposition at the margin of the inflammatory infiltrate. The control specimens responded with young, vascular reparative connective tissue at the interface. The fibroblasts in the tissue appeared normal in size but the newly formed collagen fibers were scattered and without definite orientation (Fig. 4B). The invasive crevicular epithelium reached and lined the coronal one third of the radicular notch.

Fourteen- and Twenty-One-Day Specimens. In LAPtreated specimens, a more mature reparative connective tissue was present. The cellular density in the tissues was higher than normal with fibroblasts lining the dentinal surface of the radicular notch. No new cementum was present at the notch surface (Fig. 5A). The control specimens demonstrated less dense reparative tissue with collagenous bundles loosely arranged and the cellularity not as intense as in the LAP-treated specimens. The proliferating crevicular epithelium migrated apically, reaching the radicular notch (Fig. 5B).

Twenty-Eight and Forty-Five-Day Specimens. The histological aspect of the regenerated tissue, in LAPtreated specimens, was of a cellular scar composed of packed or dispersed fibroblasts, scattered vascular channels and few inflammatory cells. No cementum deposition was evident in these specimens yet. The connective tissue fibers showed close adaptation to the dentinal root surface (Fig. 6A). The corresponding control specimens also showed progressive collagenization, diminution in blood vessels and few inflammatory cells. However, most of these specimens demonstrated epithelium extending to the radicular notch (Fig. 6B).

\section{Histometric}

Table 1 shows the results of the paired $t$ test between LAP-treated and control quadrants at each time point. Differences were computed in the direction LAP-control. $N=2$ monkeys were used for each comparison. The paired $t$ test showed significant differences between LAP-treated and control quadrants for at least some of the measurements at every time point except 14 days. It should be noted that due to the small sample size available for each comparison $(N=2)$, the power of 

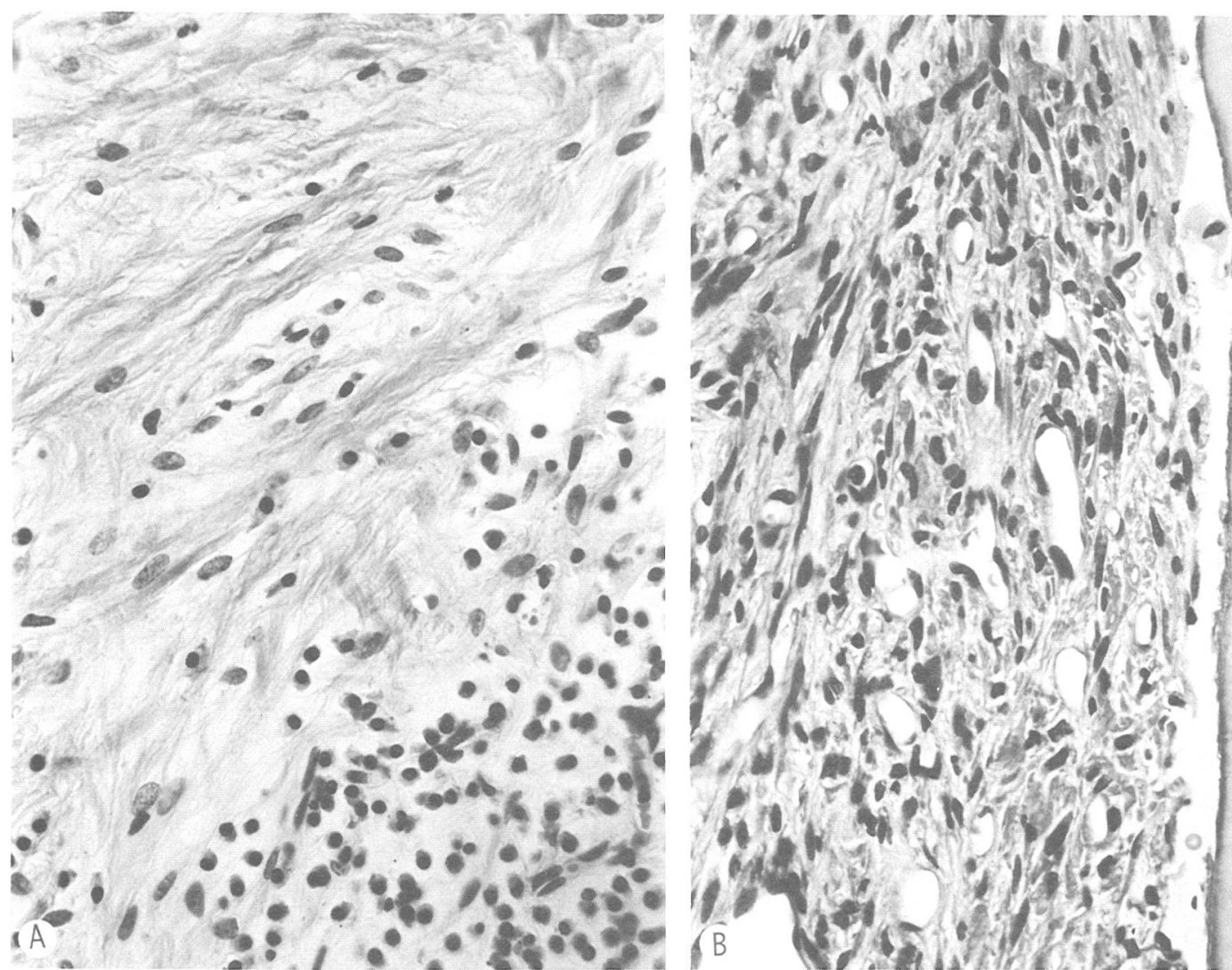

Figure 4. Seven-day specimens. A. LAP-treated. Enlarged fibroblasts and young collagenous bundles predominate in the reparative tissue that fills the interface. B. Control. The reparative tissue denotes an abundant vascularity, normal fibroblasts and disarranged collagenous fibers (hematoxylin and eosin, magnification $\times 200$ ).
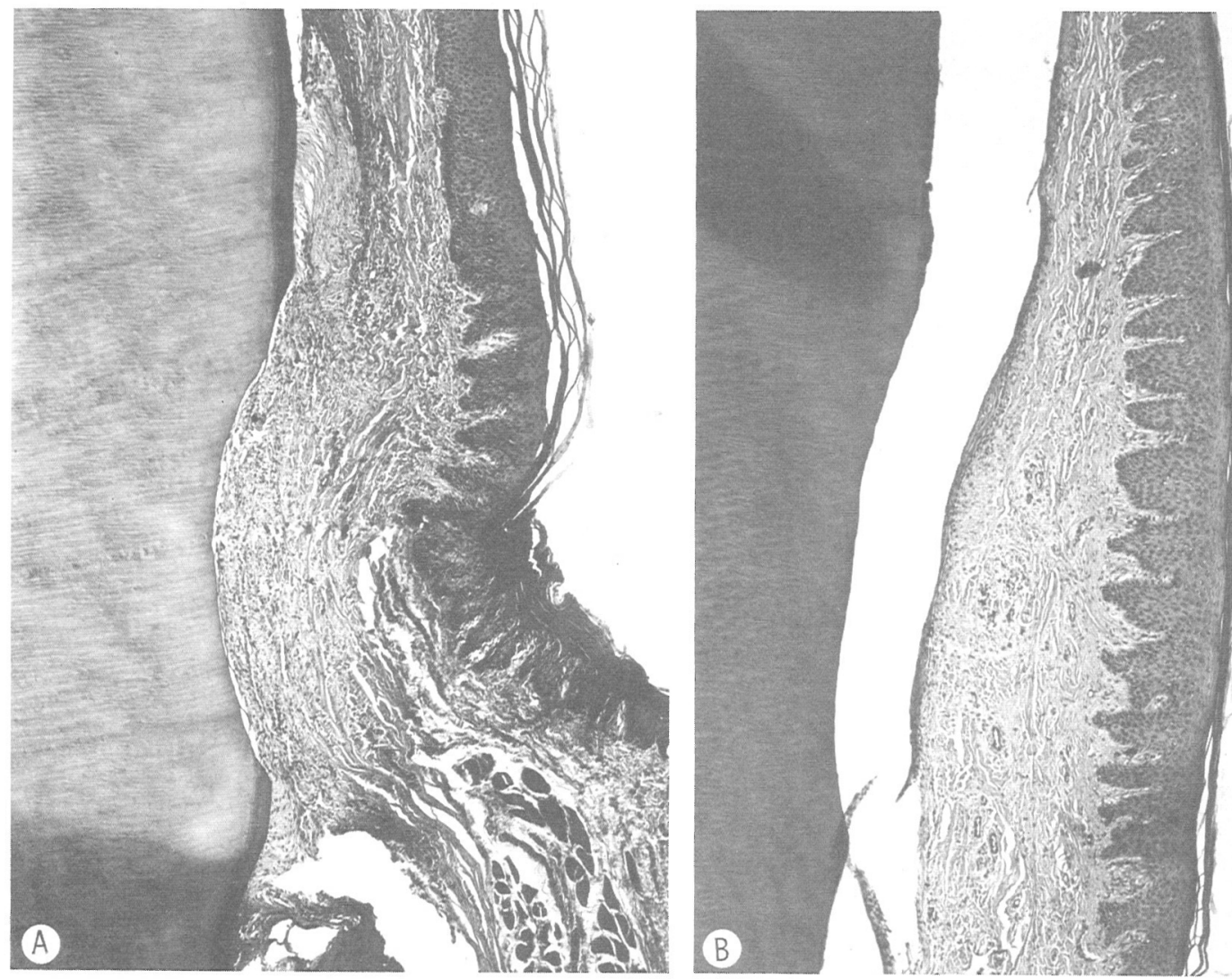

Figure 5. Fourteen-day specimens. A. LAP-treated. The reparative tissue has a more mature appearance and the cellular density appears higher than normal. Fibroblasts lined the dentinal surface of the radicular notch. No new cementum was observed at the notch surface. B. Control. The proliferating crevicular epithelium has migrated apically reaching the radicular notch (hematoxylin and eosin, magnification $\times 25$ ). 


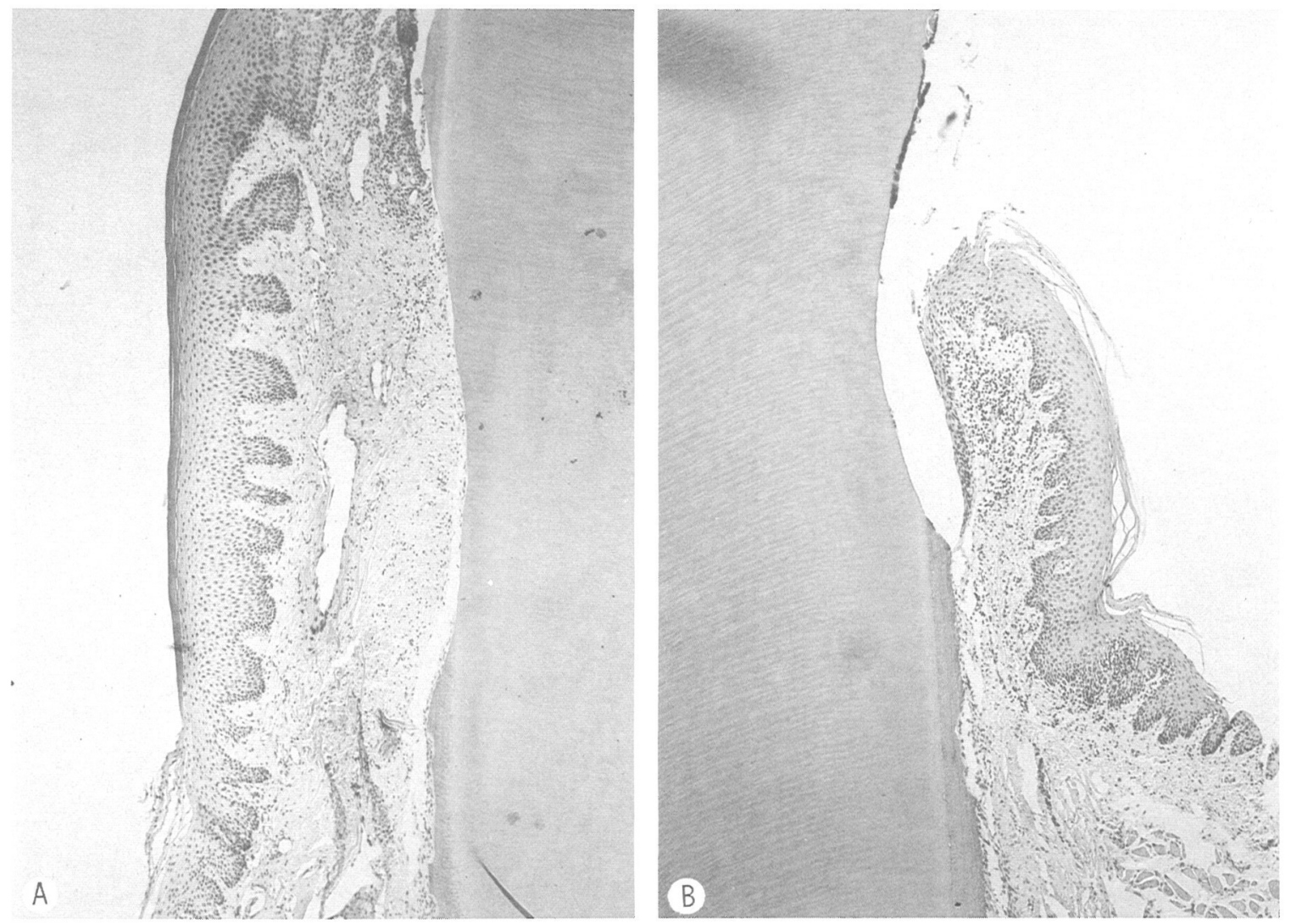

Figure 6. Forty-five day specimens. A. LAP-treated. The reparative tissue impresses as a cellular scar with scattered vascular channels, few inflammatory cells and dispersed fibroblasts. B. Control. A gingival recess uncovered the radicular notch (hematoxylin and eosin, magnification $\times 16)$.

each test is relatively low. Those $P$ values of the order of 0.07 or 0.08 may be considered suggestive of real differences which might well be confirmed in a more definite study based on a larger sample size.

\section{Autoradiographic}

Table 2 shows the results of the paired $t$ test between LAP-treated and control quadrants at each time point. Differences were also computed in the direction LAP. control, and $N=2$ monkeys were used for each comparison. The paired $t$ test did not reveal statistically significant differences between the LAP-treated and control quadrants except in a few instances. It can be noted nonetheless, that a consistent trend appears in these data. With the exception of compartment three at 45 days, the plasma-treated quadrants demonstrate more labeled cells than the control quadrants.

\section{DISCUSSION}

The results of this study have demonstrated that citric acid conditioning followed by LAP application may exert some differences on connective tissue new attachment following modified Widman flap surgery in monkeys. Although not all the differences reached significance, a trend favoring the experimental regimen can be observed.
It is not too surprising that the use of LAP could increase the connective tissue attachment to the root surface. As previously mentioned, a recent study from this laboratory has dealt with the effect of LAP application on periodontal healing of replanted teeth. ${ }^{8}$ That study demonstrated that LAP enhariced healing by: (1) early replacement of the fibrin clot, (2) increased connective tissue cell proliferation, (3) reduction of the inflammatory response, and (4) inhibition of root cementum resorption. Thus, teeth that received LAP attained much greater connective tissue reattachment than LAP-untreated teeth. However, how LAP improved healing could not be ascertained in that study. It was postulated that the components present in LAP, such as fibronectin (FN), fibrinogen, plasma factor XIIIa, and Cohn fraction IV $_{1}$ provided a cumulative effect on healing, which would account for the favorable results obtained. ${ }^{8}$

It is also possible that any of the components present in LAP, acting as single agents, or some combination of them, may account for the results. Since FN promotes cell adhesion and cell-cell interaction in $v i$ tro, ${ }^{12-16}$ it is likely that $\mathrm{FN}$ is responsible for these functions in vivo as well. It has been suggested that FN may anchor a blood clot to surrounding collagen since it is covalently linked to fibrin and collagen by plasma factor XIIIa. ${ }^{12} \mathrm{FN}$, bound to a fibrin clot, might provide 
Table 1

Results of the Paired t Test between LAP-Treated and Control Quadrants at Each Time Point. Differences Were Computed in the Direction LAP-Control*

\begin{tabular}{|c|c|c|c|c|}
\hline Days & Measurement & $\begin{array}{c}\text { Mean } \\
\text { difference } \dagger\end{array}$ & $\begin{array}{l}\text { Standard deviation } \\
\text { of difference }\end{array}$ & $\begin{array}{c}P \\
\text { value }\end{array}$ \\
\hline \multirow{3}{*}{3} & 1 & -0.12 & 0.014 & 0.05 \\
\hline & 2 & -0.03 & 0.254 & 0.89 \\
\hline & 3 & -1.75 & 0.170 & 0.04 \\
\hline \multirow{3}{*}{7} & 1 & -0.19 & 0.028 & 0.07 \\
\hline & 2 & -0.31 & 0.028 & 0.04 \\
\hline & 3 & -1.82 & 0.014 & 0.003 \\
\hline \multirow{3}{*}{14} & 1 & 0.18 & 0.071 & 0.18 \\
\hline & 2 & 0.60 & 0.311 & 0.22 \\
\hline & 3 & 0.07 & 0.141 & 0.61 \\
\hline \multirow{3}{*}{21} & 1 & -0.36 & 0.014 & 0.02 \\
\hline & 2 & 0.11 & 0.467 & 0.80 \\
\hline & 3 & -0.34 & 0.071 & 0.09 \\
\hline \multirow{3}{*}{28} & 1 & -0.02 & 0.056 & 0.70 \\
\hline & 2 & 0.83 & 0.042 & 0.02 \\
\hline & 3 & -0.42 & 0.551 & 0.48 \\
\hline \multirow{3}{*}{45} & 1 & -0.36 & 0.057 & 0.07 \\
\hline & 2 & 0.59 & 0.099 & 0.08 \\
\hline & 3 & -0.49 & 0.056 & 0.05 \\
\hline
\end{tabular}

* $N=2$ monkeys were used for each comparison.

$\dagger$ For measurements 1 and 3, a (-) indicates better result for LAP. For measurement $2, \mathrm{a}(+)$ indicates a better result for LAP.

a matrix for the motility of cells during the early healing process, ${ }^{13}$ and could act also as a primary matrix for the arrangement of collagenous fibrils during the process of regeneration and repair. ${ }^{14}$ Furthermore, FN may provide fibroblasts with at least one of the signals necessary for replication, ${ }^{15}$ and may act as an opsonin and thereby may promote the clearance of nonviable tissue and debris. ${ }^{16}$

It has been suggested that citric acid conditioning of root surfaces may stimulate cementogenesis and make possible the formation of a new fibrous connective tissue attachment to a denuded root, ${ }^{17-19}$ instead of a long junctional epithelium which has been claimed to be more unstable and less favorable,${ }^{20}$ in spite of current evidence. ${ }^{21,22}$ Caffesse et al. ${ }^{23}$ recently reported the effect of citric acid and FN application on healing following surgical treatment of naturally occurring periodontal disease in beagle dogs. That study demonstrated that: (1) root surface conditioning with citric acid, followed by topically applied FN, enhanced healing with connective tissue new attachment and (2) increased fibrous new attachment was associated with the surgery/citric acid modality, but not to the extent found when combined with FN.

Wirthlin and Hancock ${ }^{24}$ have shown that the combination of sodium desoxycholate and Cohn plasma fraction $I_{1}$ enhanced in vitro fibroblastic attachment to diseased roots, promoted connective tissue new at-
Table 2

The LAP-Treated and Control Quadrants Were Compared in Each of the Five Compartments and at Each Time Point by the Paired $t$ Test*

\begin{tabular}{|c|c|c|c|c|}
\hline Days & Compartment & $\begin{array}{c}\text { Mean } \\
\text { difference }\end{array}$ & $\begin{array}{c}\text { Standard deviation } \\
\text { of difference }\end{array}$ & $\begin{array}{c}P \\
\text { value }\end{array}$ \\
\hline \multirow{5}{*}{3} & 1 & 9.1 & 3.39 & 0.16 \\
\hline & 2 & 10.2 & 3.11 & 0.14 \\
\hline & 3 & 23.9 & 8.63 & 0.16 \\
\hline & 4 & 3.7 & 7.64 & 0.62 \\
\hline & 5 & 3.4 & 1.41 & 0.18 \\
\hline \multirow{5}{*}{7} & 1 & 36.4 & 4.24 & 0.05 \\
\hline & 2 & 32.3 & 22.77 & 0.29 \\
\hline & 3 & 35.3 & 12.30 & 0.15 \\
\hline & 4 & 0.7 & 0.71 & 0.39 \\
\hline & 5 & 7.7 & 3.39 & 0.19 \\
\hline \multirow{5}{*}{14} & 1 & 10.7 & 1.84 & 0.08 \\
\hline & 2 & 20.5 & 14.71 & 0.30 \\
\hline & 3 & 22.8 & 0.99 & 0.02 \\
\hline & 4 & 0.7 & 8.20 & 0.92 \\
\hline & 5 & 2.1 & 0.71 & 0.15 \\
\hline \multirow{5}{*}{21} & 1 & 18.7 & 20.08 & 0.41 \\
\hline & 2 & 10.9 & 0.71 & 0.03 \\
\hline & 3 & 3.1 & 0.42 & 0.06 \\
\hline & 4 & 1.8 & 0.56 & 0.14 \\
\hline & 5 & 0.7 & 0.14 & 0.09 \\
\hline \multirow{5}{*}{28} & 1 & 9.4 & 12.59 & 0.48 \\
\hline & 2 & 4.7 & 1.13 & 0.11 \\
\hline & 3 & 2.5 & 7.92 & 0.73 \\
\hline & 4 & 1.2 & 0.85 & 0.30 \\
\hline & 5 & 0.4 & 0 & $-\dagger$ \\
\hline \multirow{5}{*}{45} & 1 & 6.4 & 12.45 & 0.60 \\
\hline & 2 & 2.9 & 0 & - \\
\hline & 3 & -1.1 & 3.96 & 0.76 \\
\hline & 4 & 1.9 & 1.56 & 0.33 \\
\hline & 5 & 0.6 & 0.71 & 0.44 \\
\hline
\end{tabular}

* $N=2$ monkeys were used for each comparison.

$\dagger$ Dash indicates that the test statistic cannot be computed.

tachment and cementogenesis in monkeys, ${ }^{25,26}$ and produced a new connective tissue attachment in humans. ${ }^{27}$ This approach restored biocompatibility to diseased root surfaces by noninvasive treatment. However, the hazard of transmitting infectious agents via the pooled human plasma fraction $\mathrm{IV}_{1}$ used raised some concern. ${ }^{28-30}$ To circumvent the potential hazards of the pooled plasma fraction, Assad et al. ${ }^{31}$ evaluated the effect of sodium desoxycholate combined with whole plasma from a single donor on gingival fibroblast attachment to diseased root surfaces. Results of the study showed that the desoxycholate/plasma combination enhanced in vitro fibroblastic attachment to diseased root surfaces.

The present study was intended as a preliminary investigation, trying to determine the benefits of using autologous plasma for periodontal regeneration. If further studies confirm the trend of these initial results, the use of LAP as a tissue adhesive could become 
appealing in periodontal therapy. Sealing with this biologic adhesive, would be easily accessible due to the large quantities of plasma available in the circulating blood and to the fact that, the preparation in its lyophilized form is easy and relatively inexpensive.

The tissue sealant systems Tissucol and Tisseel, often called fibrin glues or fibrin adhesives, are currently used in Europe both widely and successfully for reuniting tissues, sealing wounds, controlling hemorrhage, and promoting wound healing in numerous surgical disciplines. ${ }^{32-39}$ They include thoracic, ${ }^{32}$ cardiovascular, ${ }^{33}$ abdominal,${ }^{34}$ neuro, ${ }^{35}$ orthopedic, ${ }^{36}$ renal, ${ }^{37}$ and maxillofacial and oral surgery. ${ }^{38.39}$ As previously mentioned, ${ }^{2-6}$ fibrin sealants have been tested both in the fixation of periodontal grafts and flaps and in obtaining connective tissue new attachment in cases of periodontitis. $^{40-42}$

Despite generalized acceptance and use in Europe, fibrin glues have received little or no attention in the United States. In a large part this stems from the fact that biologic glues are prepared from pooled human blood plasma and thus carry the potential risk of transmitting viral infection like hepatitis B, acquired immunodeficiency syndrome (AIDS), and other blood transmitted diseases. ${ }^{43-45}$ To preclude these risks, a new fibrin sealant Beriplast 1 has been introduced recently, ${ }^{46}$ in which potential viral contaminants are inactivated by pasteurization of the human plasma components. Furthermore, a cryoprecipitation technique for preparation of fibrin glue from single-donor fresh-frozen plasma has been described. ${ }^{47}$

I Behringwerke AG, Marburg/Lahn, Federal Republic of Germany.

\section{REFERENCES}

1. Oestmann, B.: Die beseitigung der vertieften zahnfleischtasche ohne abtragung der taschenwand. Paradentium (Zahnärztl Rundschau) 3: 46, 1939.

2. Bartolucci, E. G., and Pini Prato, G.: Preliminary observations on the use of a biologic sealing system (Tissucol) in periodontal surgery. J Periodontol 53: 731, 1982.

3. Pini Prato, G., De Paoli, S., Clauser, C., and Bartolucci, E. G.: On the use of a biologic sealing system (Tissucol) in periodontal surgery. Int J Periodont Rest Dent 4: 49, 1983.

4. Pini Prato, G. P., De Paoli, S., Cortellini, P., et al.: On the use of a biologic sealing system (Tissucol) in periodontal therapy. II. Histologic evaluation. Int J Periodont Res Dent 3: 33, 1985.

5. Ripamonti, U., and Lemmer, J.: New attachment after the use of a fibrin adhesive system in periodontal surgery. $J$ Periodontol 55: $727,1984$.

6. Topoll, H. H.: Die bildung eines bindegewebigen attachments nach anwendung von zitronensäure und fibrinkleber. Dtsch Zahnärztl Z 41: 613, 1986.

7. Caton, J. G., Polson, A. M., Pini Prato, G. P. et al.: Healing after application of tissue adhesive material to denuded and citric acid-treated root surfaces. J Periodontol 6: 385, 1986.

8. Nasjleti, C. E., Caffesse, R. G., Castelli, W. A., et al.: Effect of lyophilized autologous plasma on periodontal healing of replanted teeth. J Periodontol 9: 568, 1986.

9. Ramfjord, S. P., and Nissle, R. R.: The modified Widman flap.
J Periodontol 45: 601, 1974.

10. Joftes, D. L.: Radioautography, principles and procedures. $J$ Nucl Med 4: 143, 1963.

11. Glantz, S. A.: Primer of Biostatistics, New York, McGrawHill Book Co, 1981.

12. Polson, A. M., and Proye, M. P.: Fibrin linkage: a precursor for new attachment. J Periodontol 54: 141, 1983.

13. Ruoslahti, E., Hayman, G., and Engvall, E.: Molecular interactions of fibronectin. Prog Clin Biol Res 41: 821, 1980.

14. Headman, K., Vaheri, A., and Wartiovaara, J.: External fibronectin of cultured human fibroblasts is predominantly a matrix protein. J Cell Biol 76: 748, 1978.

15. Bitterman, P. B., Rennard, S. I., Adelberg, S., and Crytal, R. G.: Role of fibronectin as a growth factor for fibroblasts. $J$ Cell Biol 97: 1925, 1983.

16. Pommier, C. G., Inada, S., Fries, L. F., et al.: Plasma fibronectin enhances phagocytosis of opsonized particles of human peripheral blood monocytes. J Exp Med 157: 1844, 1983.

17. Liu, W. J., and Solt, C. W.: A surgical procedure for the treatment of localized gingival recession in conjunction with root surface citric acid conditioning. J Periodontol 51: 505, 1980.

18. Polson, A. M., and Proye, M. P.: Effect of root surface alterations on periodontal healing. II. Citric acid treatment of the denuded root. J Clin Periodontol 9: 441, 1982.

19. Frank, R. M., Fiore-Donno, G., and Cimasoni, G.: Cementogenesis of soft tissue attachment after citric acid treatment in a human. An electron microscopy study. J Periodontol 54: 389, 1983.

20. Corn, H., and Marks, M. H.: Gingival grafting for deep-wide recession. A status report. Part I. Rationale, case selection and root preparation. Compend Cont Educ Dent 4: 53, 1983.

21. Magnusson, I., Runstad, L., Nyman, S., and Lindhe, J.: A long junctional epithelium-a locus minoris resistiae in plaque infection? J Clin Periodontol 10: 333, 1983.

22. Beaumont, R. H., O'Leary, T. J., and Kafrawy, A. H.: Relative resistance of long junctional epithelial adhesions and connective tissue attachment to plaque-induced inflammation. J Periodontol 55: 213, 1984.

23. Caffesse, R. G., Holden, M. J., Kon, S., and Nasjleti, C. E.: The effect of citric acid and fibronectin application on healing following surgical treatment of naturally occurring periodontal disease in beagle dogs. J Clin Periodontol 12: 578, 1985.

24. Wirthlin, M. R., and Hancock, E. B.: Biologic preparation of diseased root surfaces. J Periodontol 51: 291, 1980.

25. Wirthlin, M. R., Hancock, E. B., and Gaughler, R. W.: Regeneration and repair after biologic treatment of root surfaces in monkeys. I. Facial surfaces maxillary incisors. J Periodontol 52: 729, 1981.

26. Wirthlin, M. R., and Hancock, E. B.: Regeneration and repair after biologic treatment of root surfaces in monkeys. II. Proximal surfaces posterior teeth. J Periodontol 53: 302, 1982.

27. Wirthlin, M. R.: Human Histologic Repair and Regeneration After Biologic Preparation of Diseased Root Surfaces, Publication No. NDRI-PR83-19, Bethesda, MD, Naval Medical Research and Development Command, 1983.

28. Barker, L. F., Maynard, J. E., Purcell, R. H., et al.: Hepatitis B virus infection in chimpanzees: titration of subtypes. $J$ Infect Dis 132: $451,1975$.

29. Hoofnagle, J. H., Gerety, R. J., Thiel, J., and Barker, L. F.: The prevalence of hepatitis B surface antigen in commercially prepared plasma products. J Lab Clin Med 88: 102, 1976.

30. Pattison, C. P., Klein, C. A., Leger, R. T., et al.: An outbreak of type $\mathrm{B}$ hepatitis associated with transfusion of plasma protein fraction. Am J Epidemiol 103: 399, 1976.

31. Assad, D. A., Dunlap, R. M., Weinberg, S. R., and Ahl, D. R.: Biologic preparation of diseased root surfaces-an in vitro study. J Periodontol 58: 30, 1987.

32. Thetter, O.: Fibrin adhesive and its application in thoracic surgery. Thorac Cardiovasc Surg 29: 290, 1981. 
33. Köveker, G., Vivie, E. R., and Hellberg, K. D.: Clinical experience with fibrin glue in cardiac surgery. Thorac Cardiovasc Surg 29: 287, 1981.

34. Marezell, A., Efferdinger, F., Spoula, H., and Stierer, M.: Anwendungsbereiche des fibrinklebers in der abdominalchirurgie. Acta Chir Aust 11: 137, 1979.

35. Kuderna, H., Dinges, H., and Readl, H.: Die fibrinklebung in der mikrochirurgie der peripheren nerven. Hefte zur Unfallfallheilk 148: $822,1980$.

36. Bösch, P., Nowotny, C., Schwägerl, W., et al.: Uber die wirkung des fibrinklebesystems bei orthopädischen operationen an hämophilen und bei anderen blutgerinnungsstörungen. Fibronogen, fibrin und fibrinkleber. K. Schimpf (ed), 23rd meeting, Dtsch Arbeitsgem Blutgerinhungsforschung, pp 275-277. Stuttgart, F. K. Schattaur Verlag, 1980.

37. Urlesberger, H., Rauchenwald, K., and Henning, K.: Fibrin adhesives in surgery of the renal parenchyma. Eur Urol 5: 260, 1979.

38. Petersen, J. K.: Clinical experience in oral surgery with human fibrin sealant. Int Dent J 35: 277, 1985.

39. Matras, H.: Fibrinseal: The state of the art. J Oral Maxillofac Surg 43: 605, 1985.

40. Pini Prato, G. P., De Paoli, S., Clauser, C., and Bartolucci, E.:
L'utilizzazione di un collante biologico (Tissucol) in chirurgia parodontale. Riv Int Parodon Odont Ricostr 4: 9, 1983.

41. Calandriello, M., Bernardi, F., and Sild, E.: Considerazioni conclusive sull'uso della colla di fibrina in chirurgia parodontale. Controlli istologici. Min Stom 34: 789, 1985.

42. Urbani, G., and Bogini, A.: Human fibrin glue and its use in periodontal surgery. G Stomatol Ortognatodonzia 3: 3, 1985.

43. Revocation of fibrinogen licenses. FDA Drug Bull 8: 15, 1978.

44. Bove, J. R.: Fibrinogen-Is the benefit worth the risk? Transfusion 18: 129, 1978.

45. Gerety, R. J., and Aronson, D. L.: Plasma derivatives and viral hepatitis. Transfusion 22: 347, 1982.

46. Hilfenhaus, J., and Weidmann, E.: Fibrin glue safety: Inactivation of potential viral contaminants by pasteurization of the human plasma components. Arzneimittelforschung 35: 1617, 1985.

47. Dresdale, A., Rose, E. A., Jeevanandam, V., et al.: Preparation of fibrin glue from single-donor fresh-frozen plasma. Surgery 97: 750, 1985.

Send reprint requests to: Dr. Carlos E. Nasjleti, Dental Research Section, Veterans Administration Medical Center, 2215 Fuller Road, Ann Arbor, MI 48105. 